Jesús L. Chirinos 1,2

Claire Brindis 2

Sheri Tye 2

Virginia McCarter 2

\section{Differences and similarities in sexual and contraceptive knowledge, attitudes, and behavior among Latino male adolescent students in California, United States and Lima, Peru}

\author{
Diferencias y similitudes en el conocimiento, \\ las actitudes y los comportamientos sexuales \\ y de anticoncepción entre estudiantes \\ adolescentes varones latinos en California, \\ Estados Unidos, y en Lima, Perú
}

\footnotetext{
1 Instituto de Estudios de Población, Universidad Peruana Cayetano Heredia. Av. Honorio Del gado 430 San Martín de Porras, Lima 18, Peru.

2 Center for Reproductive Health Policy Research, Institute for Heal th Policy Studies, University of California at San Francisco. 3333 California St., Room 265, San Francisco, CA 94143-0936, United States of America.
}

Abstract To identify the differences and similarities in sexual and contraceptiveknowledge, attitudes, and behavior among Latino male adolescent students living in California and Lima. Self-administered, anonymous surveys were completed by Latino male stu dents aged 12-19 participating in California, and by maleadolescent students in four high schools in Lima. Both surveys contain ed simi lar questions al lowing for compari sons regarding sexual activity and contraceptive behavior. The mean age of mal estudents were 16 and 15 years, respectively. More Cal ifornia males reported having engaged in sexual intercourse (69\% vs 43\%. The sexual debut was 13 years in both samples. More students in Californi a were aware of thei r risk of pregnancy at first sexual intercoursethan in Lima (82\% vs 50\%). One-third of the California males reported communicating with their partner about sex and contraception to be "easy" as compared to 53\% of males in Lima. More students in California reported knowing a place to obtain contraceptives if they need them ( $85 \%$ vs $63 \%$ ), having ever gotten someone pregnant ( $29 \%$ vs $7 \%$ ), and having fathered a child (67\% vs $16 \%)$.

Key words Adolescence; Sex Behavior; School Health

Resumen Identificar las diferencias y similitudes en cuanto a conocimiento, actitudes y comportami entos sexuales y de anti concepción entre los estudiantes adolescentes lati nos que viven en Cali fornia y en Lima. Estudiantes adol escentes varones latinos de 12-19 años completaron las encuestas anónimas, autoapli cables tanto en Cal ifornia como en cuatro col egi os secundarios en Lima. Ambas encuestas contenían preguntas similares con respecto a actividad sexual y comportamiento deanti con cepción. La media de edad fue de 16 y 15 años, respectivamente. Másvarones adolescentes en California señalaron haber teni do relaciones coi tales (69\% vs 43\%). Entre éstos, la media de edad de inicio sexual fue de 13 años en ambas muestras. Más estudiantes en Cal ifornia sabian del riesgo de embarazo en la primera relación sexual (82\% vs 50\%). Un tercio de los a dol escentes varones de Cal i forni a señal aron que habl ar sobre sexo y anticoncepción con su pareja es "fácil”, comparados al 53\% de los de Lima. Más estudiantes en California señalaron conocer un lugar para obtener anticoncepti vos si el los los necesitan ( $85 \%$ vs $63 \%$ ), haber embarazado a alguien al guna vez (29\% vs $7 \%$ ) y haber tenido un hijo ( $67 \%$ vs $16 \%$ ).

Palabras-clave Adolescencia; Salud Escolar; Conducta Social; Anti concepción 


\section{Introduction}

Reducing adolescent rates of unintended pregnancies (UIPs) and sexually transmitted diseases (STDs), including AIDS, has been identified as an important social goal for the late 1990s and one facing our society in the new millenium (Alan Guttmacher Institute, 1994; Ozer et al., 1997). Much has been learned about the types of pregnancy and STD interventions that work (Dryfoos, 1997; Kirby, 1997). However, an important gap is the lack of systematic information available on both adolescents and young adult males regarding their role in sharing responsibility for sexual activity and reproductive behavior and parenting, and contraceptive decision-making necessary to achieve a reduction in the incidence of UIPs and STDs (Dryfoos, 1997; Edwards, 1994; Moore et al., 1997).

Much of the surge in interest in intervention programs directed at males in recent years has been directly related to the recognition of the important and influential role that males play in femal es' contraceptive utilization, as well as their own willingness to use condoms (Brown \& Eisenberg, 1995; Moore et al., 1997; Schulte $\&$ Sonenstein, 1995). In addition, there has been a variety of interventions implemented, from school-based teen-focused contraceptive clinics to sexuality education programs, to reduce the high incidence of adolescent UIPs and STDs (Borgia et al., 1997; Kirby, 1997). While recent trends indicate some success in reducing the incidence of both problems, nevertheless, there continues to be a need to evaluate the stren gths and limitations of these programs and to develop additional strategies tailored to the unique needs of different groups of adolescents (Borgia et al., 1997; Lavin et al., 1992; Levine \& Pitt, 1995; Perry et al., 1993).

Men's involvement in decisions about sexual activity, contraception, and childbearing strongly influences sexual risk and non-risk be haviors (Burger \& Inderbritzen, 1985; Leland \& Barth, 1992; Pleck et al., 1975). Current trends in contraceptive method choice also suggest a rise in the use of condoms (Brugman et al., 1997; Witwer, 1997). Clearly, men have an important role in decision-making regarding the use of contraceptives and family planning related services. Research further substantiates the need to educate young people regarding the importance of joint responsibility in preventing pregnancies and STDs (Grady et al., 1996; Pleck et al., 1975; Schulte \& Sonenstein, 1995).

A strong focus on adolescents, and in particular, Latino youth, is necessary as a result of demographic shifts which will likely occur in this country by the year 2005. California's adolescent population is increasing at much higher rates than the overall US population (34\% versus $13 \%$, respectively), with slightly more adolescent males than females. Although the increasing numbers of adolescents reflects an ethnically diverse population, the Hispanic/ Latino adolescent population in California represented $34 \%$ of the overall Hispanic/Latino adolescent population in the United States in 1995 , and this subset is projected to have the highest growth pattern, with an increase of 58\% between 1995 to 2005 (Brindis \& Wolfe, 1997). In addition, immigrant Latino adolescents students appear to be vulnerable to engaging in risk-taking behaviors and do not exhibit the anticipated cultural protective factors associated with recent immigrants (Brindis et al., 1995).

Additional data on adolescents in the US in 1995 , documents that more than a half of males ages 15-19 had experienced sexual intercourse, and that the older the teen, the more likely he is to have had sex (Moore et al., 1998). Less than $30 \%$ of fifteen-year-old males had had sex; among 17 year-olds, close to $60 \%$ had had sex, increasing to $85 \%$ among nineteen-year-olds. Sexual activity also varies by ethnicity and age among males. For example, while $35 \%$ of Hispanic fifteen-year-olds had initiated sex, $65 \%$ were sexually active by the age of seventeen, and $87 \%$ among nineteen-year olds; in contrast, $60 \%$ of fifteen-year-old black males and $18 \%$ of fifteen-year-old whites had initiated sex. In general, teen girls tend to be close in age to their first voluntary sexual partners (61\%). However a subset of teenage males are having sex with significantly younger girls. Fully onequarter of sexually active sixteen-year-old males reported having a female partner who was 13 or 14 in the last year (Breslin, 1997; Moore et al., 1998). In addition, early sexual experience was associated with participation in other problem behaviors. Teen females whose first partner was considerably older were less likely to report having used any contraception at first sex than those whose partners were closer in age to themselves (Moore et al., 1998).

While most sexually experienced teen males had used condoms, they tend to use them inconsistently and the likelihood that a teenage male uses a condom every time he has sexual intercourse tends to decline with age. Males aged 18 and 19 are more likely to rely on female methods than are younger teens (Moore et al., 1998). Among sexually experienced males ages $15-19$, about $14 \%$ reported that they had impregnated a partner, and $6 \%$ of them indicated that they had fathered a child. About one-fifth 
of Hispanic and black sexually experienced teen age males reported causing a pregnancy, compared to one-tenth of white males, and just under ten percent of Hispanic and black males reported a birth, compared to five percent of white males (Moore et al., 1998).

Analysis of California data demonstrates that there is a substantial difference between young teenage mothers and the fathers of their babies (Bresl in, 1997). One half of babies born to California women aged 14-17 in 1993 were fathered by men aged 20 or older; on average men were 6.4 years older than women, whereas teenage fathers were only 1.5 years older than teen mothers. Among Hispanic and black teen mothers, there was a $20 \%$ less likelihood of adult paternity, as compared to infants born to white women (Breslin, 1997). Although, there are few data about reproductive experience among male adolescents in Latin America, adolescent males tend to disclose having had premarital sex more often than teen women. The proportion varies among adolescent males aged 15- 19 who disclosed having pre-marital sex across different countries (e.g. $44 \%$ in Mexico, $42 \%$ in Costa Rica, $73 \%$ in some areas of Brazil). The mean age of sexual debut wasfound to be 15 years and between one-fifth to onethird of sexually active male adolescents had their first sexual experience before turning 15 years old. Their first sexual partner was 3-4 years older. In the majority of the cities surveyed, only a minority of sexually experienced, non-married adolescent males were currently sexually active (in the last month before the survey). Few couples used a contraceptive in their first sexual intercourse, and among sexually active males aged 15-24, the percent of contraceptive use varied between $14 \%$ and $31 \%$. The likelihood of using a contraceptive method increased with age of sexual debut. Among those experiencing a pregnancy, between $76 \%$ and $84 \%$ were unintended (Robey et al., 1992).

Given the relatively limited information available on Latino adolescent males in both the United States and Latin America, there is a need to conduct research on the role of adolescent and young adult males in their sexual activity, sexual and reproductive behavior, and their participation in the decision-making process regarding having sexual relations and using contraceptives. Second, it is important to utilize this type of information to better reach and involve at-risk adolescent males in order to prevent STDs/AIDS and early UIPS and their consequences. Third, given the likely increase in the presence of the Hispanic population in the United States, it is important to identify similarities and differences between Hispanic/ Latino populations in different settings in order to better understand the individual and group characteristics and the effect of the social context in which they live.

In this study, we compare survey data collected between November, 1996 and March, 1997 from the Male Involvement Program, a male focused teenage pregnancy prevention program developed in 23 sites in California and the Prevention of Sexual Risk Behavior: A School-Based Sex Education Intervention Model, conducted between April, 1995 and November, 1996 in Lima, Peru. Several survey items were analyzed to identify differences and similarities in sexual and contraceptive knowledge, attitudes, and behavior among adolescent male students in order to identify critical issues for improving these prevention programs and for implementing new interventions aimed at young Latino men. We were also interested in assessing the similarities and differences between these two groups of Latino male adolescents.

\section{Methods}

A self-administered, anonymous questionnaire was completed by students ages 12 to 19 in the 3 rd and 4 th grades (equivalent to 9 th and 10th grades in the United States) attending four high schools in Lima, Peru. The schools were randomly selected from a pool of 12 schools in an urban school district which met criteria for participation, including a similar mixture of low income students, school size, and similar numbers of students who had been referred for health services by school administrators. The 50-item instrument was comprised of questions covering six areas: (1) socio-demographic information; (2) family characteristics; (3) personal activities; (4) knowledge and attitudes regarding sexuality; (5) sexual experience; and (6) contraceptive use. Data was gathered as part of a baseline survey whose findings were used to develop a school-based sexuality education program.

In California, an anonymous, self-administered survey was completed by mal es participating in the Male Involvement Program (MIP). The program, funded by the California Department of Health Services, aims to increase community awareness regarding the role of males in preventing teenage pregnancy. A 24-item instrument was used to collect socio-demographic data on participants, as well as to assess their knowledge, attitudes, and behavior regarding 
sexual activity, contraception, and pregnancy. Males were recruited from a variety of settings, including middle and high schools, juvenile justice facilities, alternative schools, youth and recreation centers, and adult jail facilities. For this study, Latino mal e students currently attending school ages 12 to 19 were selected to allow for comparative analysis.

For this study, we used comparable questions related to age, males' most important activities, their knowledge of pregnancy risk at the first act of intercourse, ease in talking about contraceptives with partners, males' sense of responsibility to avoid a pregnancy, knowledge about where to get contraceptives, whether the teen had ever had sex, age of sexual debut, use and type of contraceptive at the last act of intercourse, whether participant had ever gotten someone pregnant, and if they had fathered a child.

Age categories were defined statistically in order to weight the cells, with early adolescents defined as 12 to 14 years, middle adolescents as 15 years, and late adolescents as 16 to 19 years. These breakdowns reflect the major age groups participating in this study. Sexual activity was defined by whether the teen reported having ever engaged in sex.

\section{Results}

A total of 1,020 surveys were administered in Lima; of these surveys, 991 (97\%) met data qual ity criteria and were included in this analysis. A total of 2,071 surveys were collected from MIP participants in California; of these, 836 (40\%) met selection criteria for subsequent comparable analysis (i.e. Latino males, in this case, primarily of Mexican descent, ages 12-19 who were attending school). Characteristics of males in both samples are presented in Tables 1 and 2 , and by age in Tables 3 and 4 . Sexually active was analyzed as a dependent variable and significant results are presented in Table 5 and 6. Variables with an RR equal or greater than $\mathbf{1 . 5}$ and found to be significantly different were fitted into a regression logistic model in order to identify variables that best predict the profile of sexually active males.

The mean age of survey respondents was $14.9 \pm 1.15$ ( $n=991$, median $=15$ and range 12 19) in Lima and $15.8 \pm 1.71(n=836$, median $=$ 16 and range 12-19) in California. The self-reported preferred activity among males in both locations was spending time with family $(66 \%$ in California and 76\% in Lima, $p<0.0001$ ).

Knowledge of pregnancy risk was distinctly different among the two groups, with $82 \%$ of California Latino male students indicating awareness of their risk of pregnancy at first sexual intercourse, as compared to 50\% ( $p<0.0001)$ of males in Lima. The majority of students in both locations (85\% among the California sample and $63 \%$ among males in Lima) indicated that they know where to obtain contraceptives if they need them; California males were most likely to report drugstores (60\%) as their prima-

Table 1

Age and age of sexual debut among Latino male students. California, United Sates and Lima, Peru.

\begin{tabular}{|c|c|c|c|c|c|c|}
\hline Age (years) & $\mathrm{n}$ & $\%$ & Mean & SD & Range & $p^{1}$ \\
\hline \multicolumn{7}{|l|}{ California, United States } \\
\hline Age of sexual debut & & & & & & $0.0000 *$ \\
\hline$\leq 14$ & 51 & 9.2 & 13.27 & 2.91 & 07-19 & \\
\hline 15 & 79 & 14.3 & 13.12 & 1.14 & $09-16$ & \\
\hline$\geq 16$ & 423 & 76.5 & 13.61 & 1.74 & $05-19$ & \\
\hline Total & 553 & 100.0 & 13.5 & 1.81 & 05-19 & \\
\hline \multicolumn{7}{|l|}{ Lima, Peru } \\
\hline Age of sexual debut & & & & & & $0.0000 *$ \\
\hline$\leq 14$ & 93 & 25.5 & 12.33 & 1.64 & $05-16$ & \\
\hline 15 & 122 & 33.5 & 13.13 & 1.79 & $07-15$ & \\
\hline$\geq 16$ & 149 & 40.9 & 13.89 & 2.05 & 07-19 & \\
\hline Total & 364 & 100.0 & 13.2 & 1.96 & $05-19$ & \\
\hline
\end{tabular}

SD = Standard deviation

$1 \mathrm{p}$ value for $\mathrm{F}$ statistic

* significant 
ry source of contraceptives, while Lima males reported heal th providers (81\%) as their source of contraceptives ( $p<0.0001)$.

Comfort in communicating with their partners about sex and contraception was also distinctly different between the California and Lima sample; $33 \%$ and $53 \%$ ( $p<0.0001$ ), respectively, felt it was always easy to talk to their partners. Views on responsibility for contraceptive use differed between groups; $79 \%$ and $69 \%$, respectively, $(p<0.0001)$ reported that both males and females share equal responsibility for using contraception to avoid a pregnancy.

Sexual activity was reported to have occurred more frequently in California than in Lima; $69 \%$ and $42 \%$ of students ( $p<0.0001$ ), respectively, reported having engaged in sexual activity. Among sexually active males, the mean age for sexual initiation was 13 years in both locations. Among those sexually active males, $28 \%$ and $37 \%$, respectively, reported using contraceptives at the time of their last sexual experience. The most common method of contraception was condoms, which were used in both population samples ( $83 \%$ and $84 \%$ ) at the last act of intercourse. Among sexually active males, $29 \%$ and $7 \%$ respectively, reported ever getting someone pregnant ( $p<0.0001$ ). Furthermore, $67 \%$ of California and $16 \%$ of Lima youth who had gotten their girlfriends pregnant, had also fathered a child ( $p<0.0001$ ). Reflecting the greater incidence of sexual activity and the inconsistent use of contraceptives, the incidence of adolescent pregnancy was far more likely among the California males than in Lima.

For both populations, knowledge of the risk of pregnancy at first intercourse increased by age ( $p<0.0001$ ), as did the level of comfort males reported in discussing contraception with their sexual partners $(p=0.0034)$. Not surprisingly, older teens in both samples were more likely to report having had sex and having ever gotten someone pregnant ( $p<0.0001$ and $p=0.0041$, respectively). We found significant differences in the proportion of adolescents in both samples who were sexually active (Table 5). In California, activities such as attending school ( $R R=0.82, p<0.0001)$, socializing with friends ( $R R=0.89, p<0.05)$, and sports ( $R R=0.76, p<0.0001$ ) were protective factors. However, in Lima, socializing with friends was associated with a greater likelihood of sexual activity ( $R R=1.19, p=0.0354$ ) although playing sports was a protective factor against early sexual initiation ( $R R=0.81, p=0.0104)$.

In California, knowing that pregnancy is possible at first sex $(R R=1.56, p<0.0001)$, knowing where to get contraceptives $(R R=2.04$,
Table 2

Favorite activities, sexual knowledge, attitudes, behaviors and pregnancy experience among Latino male students. California, United States and Lima, Peru.

\begin{tabular}{|c|c|c|c|c|c|}
\hline \multirow[t]{2}{*}{ Variable } & \multicolumn{2}{|c|}{ California } & \multicolumn{2}{|c|}{ Lima } & \multirow[t]{2}{*}{ p1 } \\
\hline & $\mathrm{n}$ & $\%$ & $\mathrm{n}$ & $\%$ & \\
\hline \multicolumn{6}{|l|}{ Favorite activities } \\
\hline Attending school & 896 & & 979 & & $0.0001 *$ \\
\hline Yes & 393 & 47.0 & 372 & 38.0 & \\
\hline Being with family & 836 & & 987 & & $0.0000^{*}$ \\
\hline Yes & 548 & 65.6 & 746 & 75.6 & \\
\hline Socializing with friends & 836 & & 954 & & $0.0000^{*}$ \\
\hline Yes & 374 & 44.7 & 285 & 29.9 & \\
\hline Sports & 836 & & 954 & & $0.0000^{*}$ \\
\hline Yes & 225 & 26.9 & 339 & 35.5 & \\
\hline \multicolumn{6}{|l|}{ Knowledge } \\
\hline $\begin{array}{l}\text { Pregnancy possible } \\
1 \text { st time sex }\end{array}$ & 810 & & 950 & & $0.0000 *$ \\
\hline Yes & 666 & 82.2 & 602 & 63.4 & \\
\hline $\begin{array}{l}\text { Know where to get } \\
\text { contraceptives }\end{array}$ & 810 & & 950 & & $0.0000 *$ \\
\hline Yes & 690 & 85.2 & 602 & 63.4 & \\
\hline Sources of contraceptives & 591 & & 558 & & $0.0000 *$ \\
\hline Health providers & 227 & 38.4 & 454 & 81.4 & \\
\hline Drug-stores/others & 364 & 61.6 & 104 & 18.6 & \\
\hline \multicolumn{6}{|l|}{ Attitudes } \\
\hline $\begin{array}{l}\text { Responsible to avoid } \\
\text { pregnancy }\end{array}$ & 806 & & 945 & & $0.0000^{*}$ \\
\hline Male or female & 170 & 21.1 & 293 & 31.0 & \\
\hline Both & 636 & 78.9 & 652 & 69.0 & \\
\hline $\begin{array}{l}\text { Easy to talk about } \\
\text { contraceptives }\end{array}$ & 788 & & 964 & & $0.0000 *$ \\
\hline Yes & 318 & 40.4 & 508 & 52.7 & \\
\hline \multicolumn{6}{|l|}{ Behaviors } \\
\hline Ever had sex & 777 & & 942 & & $0.0000 *$ \\
\hline Yes & 538 & 69.2 & 401 & 42.6 & \\
\hline $\begin{array}{l}\text { Use contraceptives last } \\
\text { time had sex }\end{array}$ & 584 & & 416 & & 0.8259 \\
\hline Yes & 223 & 38.2 & 156 & 37.5 & \\
\hline Type of contraceptive & 193 & & 126 & & 0.7692 \\
\hline Condom & 165 & 85.5 & 106 & 84.1 & \\
\hline Other methods & 28 & 14.5 & 20 & 15.8 & \\
\hline \multicolumn{6}{|l|}{ Pregnancy experience } \\
\hline Ever gotten a girl pregnant & 538 & & 401 & & $0.0000^{*}$ \\
\hline Yes & 150 & 27.9 & 31 & 7.7 & \\
\hline Ever fathered a child & 150 & & 31 & & $0.0000 *$ \\
\hline Yes & 101 & 67.3 & 5 & 16.1 & \\
\hline
\end{tabular}

$1 \mathrm{p}$ value for $\chi^{2}$

* significant 
Favorite activities, sexual knowledge and attitudes, behavior, and pregnancy experience by age among Latino male students. California, United States.

\begin{tabular}{|c|c|c|c|c|c|c|c|c|c|}
\hline \multirow[t]{2}{*}{ Variable } & \multicolumn{2}{|c|}{$\leq 14$} & \multicolumn{2}{|c|}{15} & \multicolumn{2}{|c|}{$\geq 16$} & \multicolumn{2}{|c|}{ Total } & \multirow[t]{2}{*}{$\mathrm{p}^{1}$} \\
\hline & $\mathrm{n}$ & $\%$ & $\mathrm{n}$ & $\%$ & $\mathrm{n}$ & $\%$ & $\mathrm{n}$ & $\%$ & \\
\hline Age & 186 & 22.2 & 146 & 17.5 & 504 & 60.3 & 836 & & \\
\hline \multicolumn{10}{|l|}{ Favorite activities } \\
\hline Sports & & & & & & & 836 & & $0.0025^{*}$ \\
\hline Yes & 76 & 40.9 & 44 & 30.1 & 105 & 20.8 & 225 & 26.9 & \\
\hline \multicolumn{10}{|l|}{ Knowledge } \\
\hline Pregnancy possible 1st time sex & & & & & & & 810 & & $0.0066^{*}$ \\
\hline Yes & 125 & 69.4 & 114 & 82.6 & 427 & 52.7 & 666 & 82.2 & \\
\hline Know where to get contraceptives & & & & & & & 810 & & $0.0007^{*}$ \\
\hline Yes & 133 & 74.7 & 109 & 76.8 & 448 & 91.4 & 690 & 85.2 & \\
\hline \multicolumn{10}{|l|}{ Attitudes } \\
\hline Easy to talk about contraceptives & & & & & & & 788 & & $0.0000^{*}$ \\
\hline Yes & 32 & 18.2 & 50 & 36.0 & 236 & 49.9 & 318 & 40.4 & \\
\hline \multicolumn{10}{|l|}{ Behaviors } \\
\hline Ever had sex & & & & & & & 777 & & 0.0000 \\
\hline Yes & 45 & 27.9 & 84 & 60.0 & 409 & 85.9 & 538 & 69.2 & \\
\hline \multicolumn{10}{|l|}{ Pregnancy experience } \\
\hline Ever gotten someone pregnant & & & & & & & 538 & & 0.0233 \\
\hline Yes & 10 & 22.2 & 11 & 13.1 & 129 & 31.5 & 150 & 27.9 & \\
\hline Ever fathered a child & & & & & & & 150 & & $0.9783^{*}$ \\
\hline Yes & 8 & 80.0 & 7 & 63.6 & 86 & 66.7 & 101 & 67.3 & \\
\hline
\end{tabular}

$1 \mathrm{p}$ value for $\chi^{2}$

* significant

$\mathrm{p}<0.0001$ ), and ease in speaking about sex and contraceptives with their partners were found to be associated with sexual activity. In Lima, a similar relationship was found for teenage males who reported that it is easy to talk about sex and contraceptives with their partners $(\mathrm{RR}=$ $1.43, \mathrm{p}<0.0001)$.

\section{Discussion}

This comparative study found a number of similarities and differences in these two groups of Latino youth-one living in Lima, Peru and the other, of Mexican descent, living in California. The ability to present results on these different Latino groups aims at providing important in sights into the different needs of a similar ethnic group, given cultural and contextual differences within this ethnic group.

Both samples were comparable in reporting that the most positive force in their lives are their families, but no association was found between family involvement and a reduced level of sexual activity in either group. Involvement in sports was seen to have a protective effect in delaying sexual activity in both groups, while socializing with friends was found not to be associated with sexual activity in California males, but was seen as a risk condition in Lima.

These findings support other findings which point to the importance of including peers, as well as recreational activities, such as sports, when planning strategies to delay sexual debut and prevent STDs and early pregnancy (Collins \& Repinski, 1994; Noller, 1994; Resnick et al., 1997). Although families were not found to be a protective factor in terms of sexual behavior, recent research findings make a clear case for family involvement in reducing other risk taking behaviors (Resnick et al., 1997).

We found important differences between the two samples in terms of awareness of pregnancy risk, knowledge of where to obtain contraceptives, and communication with sexual partners. Nearly two times as many California males understood their risk of pregnancy at first sexual intercourse as compared to the Li- 
Favorite activities, sexual knowledge and attitudes, behavior, and pregnancy experience by age among Latino male students. Lima, Peru.

\begin{tabular}{|c|c|c|c|c|c|c|c|c|c|}
\hline \multirow[t]{2}{*}{ Variable } & \multicolumn{2}{|c|}{$\leq 14$} & \multicolumn{2}{|c|}{15} & \multicolumn{2}{|c|}{$\geq 16$} & \multicolumn{2}{|c|}{ Total } & \multirow[t]{2}{*}{$\mathrm{p}^{1}$} \\
\hline & $\mathrm{n}$ & $\%$ & $n$ & $\%$ & $\mathrm{n}$ & $\%$ & $\mathrm{n}$ & $\%$ & \\
\hline Age & 394 & 39.8 & 327 & 33.0 & 270 & 27.2 & 991 & & \\
\hline \multicolumn{10}{|l|}{ Favorite activities } \\
\hline Being with family & & & & & & & 987 & & $0.0201 *$ \\
\hline Yes & 311 & 79.3 & 250 & 76.7 & 185 & 68.8 & 746 & 75.6 & \\
\hline Socializing with friends & & & & & & & 954 & & $0.0042 *$ \\
\hline Yes & 91 & 23.9 & 107 & 34.2 & 87 & 33.5 & 285 & 29.9 & \\
\hline \multicolumn{10}{|l|}{ Knowledge } \\
\hline Pregnancy possible 1 st time sex & & & & & & & 963 & & $0.0000 *$ \\
\hline Yes & 180 & 46.3 & 161 & 50.3 & 138 & 54.3 & 479 & 49.7 & \\
\hline \multicolumn{10}{|l|}{ Attitudes } \\
\hline Easy to talk about contraceptives & & & & & & & 964 & & $0.0034 *$ \\
\hline Yes & 179 & 45.9 & 170 & 53.0 & 159 & 62.8 & 508 & 52.7 & \\
\hline \multicolumn{10}{|l|}{ Behaviors } \\
\hline Ever had sex & & & & & & & 942 & & $0.0000 *$ \\
\hline Yes & 110 & 29.5 & 134 & 43.2 & 157 & 60.6 & 401 & 42.6 & \\
\hline \multicolumn{10}{|l|}{ Pregnancy experience } \\
\hline Ever gotten someone pregnant & & & & & & & 401 & & 0.0845 \\
\hline Yes & 6 & 5.4 & 5 & 3.7 & 20 & 12.7 & 31 & 7.7 & \\
\hline Ever fathered a child & & & & & & & 31 & & \\
\hline Yes & 1 & 16.7 & 0 & 0 & 4 & 20.0 & 5 & 16.1 & \\
\hline
\end{tabular}

$1 \mathrm{p}$ value for $\chi^{2}$

* significant

ma sample. The majority in both locations know where to obtain contraceptives if they need them, but the options may be more limited in Lima, where the overwhelming majority cited health providers as their resource of care. In contrast to obtaining condoms through drugstores or a system of free-standing family planning clinics providing free or reduced cost family planning care, accessing contraceptives through the health care system in Lima requires setting up an appointment, future planning, and sufficient trust of a medical provider. There are also fewer confidentiality guidelines embedded in the Peruvian heal th care system in contrast to the United States.

Although condoms may be more readily available to California youth, there may still be embarrassment in purchasing contraceptive supplies. In spite of knowing where they can access birth control, two-thirds of students in California indicated that it is difficult to talk about sex and contraceptives with their partners, as compared to half of respondents in Lima. These findings are important in order to evaluate the relationship between the knowledge base of adolescent males, their attitudes regarding sex and contraception, and their level of comfort in discussing these topics with their sexual partners (Huerta-Franco et al., 1996; Leland \& Barth, 1992; Millan et al., 1995). The level of communication is an important factor because research has demonstrated that the consistent use of contraceptives is more likely when there is open communication between sexual partners about contraceptive usage (Leland \& Barth, 1992; Wilson et al., 1994).

Despite this discomfort, nearly two-thirds of California males and one-half of participants in Lima, initiated their sexual activity at an early age. Similar findings for males have been documented in other studies in both North and South-American samples (CDC, 1992; Lauritsen \& Swicegood, 1997; Morris, 1988; Walrond et al., 1993). Early sexual activity places males at risk of acquiring an STD or causing an unintended pregnancy. Younger males may be less likely to recognize their risk or feel they are somehow invulnerable to such 


\begin{tabular}{|c|c|c|c|c|c|c|}
\hline \multirow[t]{2}{*}{ Variable } & \multicolumn{2}{|c|}{ Sexually active } & \multicolumn{2}{|c|}{ Non-sexually active } & \multirow[t]{2}{*}{$\mathrm{RR}(\mathrm{Cl} 95 \%)$} & \multirow[t]{2}{*}{$\mathrm{p}$} \\
\hline & $\mathrm{n}$ & $\%$ & $n$ & $\%$ & & \\
\hline \multicolumn{7}{|l|}{ California, United States } \\
\hline \multicolumn{7}{|l|}{ Favorite activities } \\
\hline Attend school & 538 & & 239 & & $0.8(0.75-0.91)$ & $0.0000^{*}$ \\
\hline Yes & 225 & 62.1 & 137 & 37.9 & & \\
\hline Socializing with friends & 538 & & 239 & & $0.89(0.80-0.98)$ & $0.0133^{*}$ \\
\hline Yes & 221 & 64.6 & 121 & 35.4 & & \\
\hline Sports & 538 & & 239 & & $0.76(0.67-0.87)$ & $0.0000^{*}$ \\
\hline Yes & 114 & 56.2 & 89 & 43.8 & & \\
\hline \multicolumn{7}{|l|}{ Knowledge } \\
\hline Pregnancy possible 1st time sex & 533 & & 235 & & $1.5(1.30-1.88)$ & $0.0000^{*}$ \\
\hline Yes & 470 & 74.0 & 165 & 26.0 & & \\
\hline Know where to get contraceptives & 534 & & 237 & & $2.0(1.60-2.62)$ & $0.0000^{*}$ \\
\hline Yes & 493 & 74.8 & 166 & 25.2 & & \\
\hline \multicolumn{7}{|l|}{ Attitudes } \\
\hline Easy to talk about contraceptives & 517 & & 228 & & $1.6(1.50-1.80)$ & $0.0000 *$ \\
\hline Yes & 274 & 90.4 & 29 & 9.6 & & \\
\hline \multicolumn{7}{|l|}{ Lima, Peru } \\
\hline \multicolumn{7}{|l|}{ Favorite activities } \\
\hline Socializing with friends & 384 & & 526 & & $1.1(1.02-1.39)$ & $0.0354 *$ \\
\hline Yes & 130 & 47.4 & 144 & 52.6 & & \\
\hline Sports & 384 & & 526 & & $0.8(0.68-0.96)$ & $0.0104^{*}$ \\
\hline Yes & 116 & 36.5 & 202 & 63.5 & & \\
\hline \multicolumn{7}{|l|}{ Attitudes } \\
\hline Easy to talk about contraceptives & 392 & & 527 & & $1.4(1.22-1.67)$ & $0.0000^{*}$ \\
\hline Yes & 241 & 49.7 & 244 & 50.3 & & \\
\hline
\end{tabular}

a risk (Morris, 1988; Pleck et al., 1993; Weisman, 1989). These risk behaviors may be further reinforced by their short-term positive effects, such as sexual pleasure and approval from peers in spite of the potential negative repercussions, such as a pregnancy or STD, which they may not always experience (Hunter \& Schaechner, 1992).

It is important to emphasize that only onethird of males in California, as well as in Lima, reported using contraception at the time of their last act of intercourse. Among those who used contraception, the majority chose a condom, suggesting a level of knowledge and intention of protecting themselves against STDs, as well as an unintended pregnancy. However, for the majority of students in both samples, the risk for both was not effectively reduced because condoms were not used consistently by the males (Brugman et al., 1997; Millan et al., 1995; Pleck et al., 1993).
The limitations of this study are primarily related to the collection of sensitive data in school settings, and thus results can only be generalized to populations with similar characteristics. In addition, there was a difference of approximately one year between samples thus potentially impacting the study results.

In spite of these limitations, these findings have important implications for future efforts to address the male role in STD and pregnancy prevention efforts, including increasing healthy activities as an alternative to early sexual involvement. Building adolescents' knowledge in order to avoid risky behaviors is also an important strategy. Although knowledge alone is insufficient to assure behavioral change, it is an important cornerstone in assuring that adolescents have a solid knowledge base upon which they can make decisions. Combined with experientially-based educational strategies, as well as broader-based efforts aimed at changes in 
social norms, adolescent males may be able to increase their level of comfort in discussing the topic of sexuality and contraceptive use with their partners.

It is also important to begin to ascertain how to more actively engage families and peers in conveying and reinforcing messages regarding the need for responsible sexual behavior, such as the value of abstinence and/or the use

\section{Acknowledgement}

We would like to acknowledge the Office of Family Planning's M ale Involvement Program in California, United States and the Prevention of Sexual Risk Behavior: An School-Based Sex Education Intervention Model in Lima, Peru funded by Ford Foundation (Grant 950-0442).

\section{References}

ALAN GUTTMACHER INSTITUTE, 1994. Sex and America's Teenagers. New York: Allan Guttmacher Institute.

BORGIA, P.; SPADEA, T.; PERUCCI, C. A.; DE PASCALI, V.; FANO, V.; SCHIFANO, P. \& ABENI, D. D. C., 1997. Limited effectiveness of a school-based HIV prevention campaign in Italy. A randomized controlled trial. European Journal of Public Health, 7:411-417.

BRESLIN, M., 1997. Adult partners of teenage mothers frequently have an inadequate education. Family Planning Perspectives, 29:238- 239.

BRINDIS, C. \& WOLFE, A., 1997. Trends in Adolescent Population Growth in California and in the United States 1995-2005. San Francisco: National Adolescent Health Information Center, Department of Pediatrics, Division of Adolescent Medicine and Center for Reproductive Health Policy Research, University of California. (mimeo.)

BRINDIS, C. D.; IRWIN Jr., C. E.; OZER, E. M.; HADLEY, M.; KNOPF, D. K. \& MILLSTEIN, S. G., 1997. Improving Adolescent Health: An Analysis and Synthesi s of Health Policy Recommendations. San Francisco: National Adolescent Health Information Center, University of California.

BRINDIS, C.; WOLFE, A. L.; MCCARTER, V.; BALL, S. \& STARBUCK-M ORALES, S., 1995. The associations between immigrant status and risk-behavior patterns in Latino adolescents. Journal of Adolescent Health, 17:99- 105. of contraceptives if the adolescent becomes sexually active. This research provides the basis for planning especially tailored strategies aimed at creating a positive change in adolescent male attitudes and behavior, thus potentially resulting in improved preventive programs aimed at reducing the rates of STDs and unintended pregnancies among adolescents, particularly of Latino descent.
BROWN, S. \& EISENBERG, L., 1995. The Best Intentions. Washington, DC: National Academy Press.

BRUGM AN, E.; VOGELS, T. \& VAN ZESSEN, G., 1997. Trends in sexual risk behaviour among Turkish/Moroccan adolescents in the Netherlands 1990-1995. European Journal of Public Health, 7:418-420.

BURGER, J. \& INDERBRITZEN, H., 1985. Predicting contraceptive behavior among college students: The role of communication, knowledge, sexual anxiety and self-esteem. Archives of Sexual Behavior, 14:343-350

CDC (Centers for Disease Control and Prevention), 1992. Measuring the health behavior among high school students - United States, 1990. MMWR, 40: 885-888.

COLLINS, W. A. \& REPINSKI, D. J., 1994. Relationships during adolescence: Continuity and change in interpersonal perspective. In: Advances in Adolescent Development (R. Montemayor, G. R. Adanis \&T. P. Gullota, ed.), pp. 7-36, London/ New Delhi: Sage Publications.

DRYFOOS, J. G., 1988. Putting the Boys in the Picture: A Review of Programs to Promote Sexual Responsibility among Young Males. Santa Cruz: Network Publications.

EDWARDS, S. R., 1994. The role of men in contraceptive decision-making: Current knowledge and future implications. Family Planning Perspectives, 26:77-82. 
GRADY, W. R.; TANFER, K.; BILLY, J. O. G. \& LINCOLNHANSON, J., 1996. Men's perceptions of their roles and responsibilities regarding sex, contraception, and childbearing. Family Planning Perspectives, 28:221-226.

HUERTA-FRANCO, R.; DIAZ-DE-LEON , J \& \& MALACARA, J. M., 1996. Knowledge and attitudes toward sexuality in adolescents and their association with the family and other factors. Adolescence, 31:179-191.

HUNTER, J. \& SCHAECHNER, R., 1992. Adolescents and AIDS: Coping Issues. Living and Dying with AIDS. New York: Plenum Press.

KIRBY, D., 1997. No Easy Answers. Washington, DC: Task Force on Effective Programs and Research, National Campaign to Prevent Teen Pregnancy.

LAURITSEN, J. L. \& SWICEGOOD, C. G., 1997. The consistency of self-reported initiation of sexual activity. Family Planning Perspectives, 29:215221.

LAVIN, A.; SHAPIRO, G. R. \& WEILL, K. S., 1992. Creating an agenda for school-based health promotion: A review of 25 selected reports. Journal of School Health, 62:212-228.

LELAND, N. L. \& BARTH, R. P., 1992. Gender differences in knowledge, intentions, and behaviors concerning pregnancy and sexually transmitted disease prevention among adolescents. Journal of Adolescent Health, 13:589-599.

LEVINE, J. A. \& PITT, E. W., 1995. New Expectations: Community Strategies for Responsible Fatherhood. New York: Families and Work Institute.

MILLAN, T.; VALENZUELA, S. \& VARGAS, N. A., 1995. Reproductive health in adolescent students: Knowledge, attitudes, and behavior in both sexes, in a community in Santiago. Revista Medica de Chile, 123:368-375.

MOORE, K. A.; DRISCOLL, A. \& OOMS, T., 1997. Not Just for Girls: TheRole of Men and Boys in Preventing Teen Pregnancy. Washington, DC: National Campaign to Prevent Teen Pregnancy.

MOORE, K. A.; DRISCOLL, A. K. \& LINDBERG, L. D., 1998. Sexual behavior, contraceptive use, and childbearing. In: A Statistical Portrait of Adolescent Sex,Contraception, and Childbearing (K. A. Moore, A. K. Driscoll, \& L. D. Lindberg, ed.), pp. 140, Washington, DC: National Campaign to Prevent Teen Pregnancy.

MORRIS, L., 1988. Young adults in Latin America and Caribbean: Their sexual experience and contraceptive use. International Family Planning Perspectives, 14:153-158.

NOLLER, P., 1994. Relationships with parents in adolescence: Process and outcome. In: Advances in Adolescent Development (R. Montemayor, G. R. Adanis \& T. P. Gullota, ed.), pp. 37-77, London/ New Delhi: Sage Publications.
OZER, E. M.; BRINDIS, C. D.; MILLSTEIN, S. G. KNOPF, D. K. \&IRWIN, C. E., 1997. America's Adolescents: Are They Healthy?. San Francisco: National Adolescent Health Information Center, Division of Adolescent Medicine, Department of Pediatrics and Institute for Health Policy Studies, School of Medicine, University of California.

PERRY, C.; KELDER, S. \& KOMRO, K., 1993. The social world of adolescents: Families, peers, schools in the community. In: Promoting the Health of Adolescents (S. Millstein, A. Petersen \& E. Nightingale, ed.), pp. 73-96, New York: Oxford University Press.

PLECK, J. H.; SONENSTEIN, F. L. \& KU, L., 1993. Changes in adolescent males use of and attitudes toward condoms, 1988-1991. Family Planning Perspectives, 25:106-117.

PLECK, J. H.; SONENSTEIN, F. L. \& SWAIN, S. O., 1975. Adolescent male's sexual behavior and contraceptive use: Implications for male responsibility. Journal of Adolescent Research, 3:275-284.

RESNICK, M. D.; BEARMAN, P. S.; BLUM, R. W.; BAUMAN, K. E.; HARRIS, K. M., JONES, J.; TABOR, J.; BEUHRING, T.; SIEVING, R. E.; SHEW, M.; IRELAND, M.; BEARINGER, L. H. \& UDRY, J. R., 1997. Protecting adolescents from harm: Findings from the National Longitudinal Study on Adolescent Health. JAMA, 178:823-832.

ROBEY, B.; RUTSTEIN, S. \& MORRIS, L., 1992. La revolución reproductiva: Nuevos resultados de las encuestas. Population Reports, M (11):25-30.

SCHULTE, M. M . \& SONENSTEI N, F. L., 1995. Men at family planning clinics: The new patients? Family Planning Perspectives, 27:212-225.

WALROND, E.; JONES, F.; HOYOS, M.; SOUNDER, M .; ELLIS, H. \& ROACH, R., 1993. Conocimientos y actitudes de los adolescentes de Barbados sobre el SIDA. Boletín de la Oficina Sanitaria Panamericana, 114:33-44.

WEISM AN, C., 1989. AIDS knowledge, perceived risk and prevention among adolescents clients of a family planing service. International Family Planning Perspectives, 21:213.

WILSON, M. D.; KASTRINAKIS, M.; D'ANGELO, L. J. \& GETSON, P., 1994. Attitudes, knowledge, and behavior regarding condom use in urban black adolescent males. Adolescence, 29:13-26.

WITWER, M., 1997. Swiss program improves condom use, but levels of other HIV risk-related behavior are unchanged. Family Planning Perspectives, 29: 237-238. 